Jurnal Minds: Manajemen Ide dan Inspirasi

Vol. 8, No.2 (December) 2021: 237-254

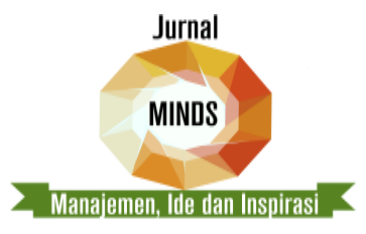

\title{
E-SERVICE QUALITY, CUSTOMER TRUST \& SATISFACTION: MARKET PLACE CONSUMER LOYALTY ANALYSIS
}

\author{
Hari Muharam $^{1 *}$, Harmon Chaniago ${ }^{2}$, Endraria ${ }^{3}$, and Amran Bin Harun ${ }^{4}$ \\ 1Universitas Pakuan, Bogor, Indonesia, \\ 2Politeknik Negeri Bandung, Indonesia \\ 3Universitas Muhammadiyah Tangerang, Indonesia \\ 4 Universiti Tun Hussein Onn, Malaysia
}

Citation (APA $7^{\text {th) }}$ : Muharam, H., Chaniago, H., Endraria, E., \& Harun, A. B. (2021). E-Service Quality, Customer Trust and Satisfaction: Market Place Consumer Loyalty

Analysis. Jurnal Minds: Manajemen Ide Dan Inspirasi, 8(2), 237-254. https://doi.org/10.24252/minds. v8i2.23224

Submitted: 21 August 2021

Revised: 7 September 2021

Accepted: 13 September 2021

Published: 21 September 2021

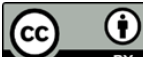

Copyright: (c) 2021 by the authors.
ABSTRACT: Why do online customers become loyal in their purchases on e-commerce sites? We examine how e-service quality, trust, and customer satisfaction affect customer loyalty towards purchasing goods and services. The proposed model also investigates the relationships among e-service quality, trust to loyalty, and satisfaction as a mediator that remains underexplored. The sample of this study is 350 millennial respondents as online buyers in Bogor city. PLS-SEM modeling procedure was used to test the proposed research model. We find that the quality of e-service and trust has a significant favorable influence on customer loyalty, and this effect is mediated by customer satisfaction. This study highlights the role of e-commerce producers in gaining loyalty through efficient service offerings and shape positive psychological in online marketing practices.

Keywords: E-Service Quality; Trust; Customer Satisfaction; Loyalty

*Corresponding Author : hari.muharam@unpak.ac.id

DOI: $10.24252 /$ minds.v8i2.23224

ISSN-E: 2597-6990

ISSN-P: 2442-4951

http://journal.uin-alauddin.ac.id/index.php/minds 


\section{INTRODUCTION}

Online shopping as a phenomenon in various fields at present and future is an exciting topic to study and research. Based on the report of the Indonesian internet service providers association 2019-2020, e-commerce websites are known to the public and the prominent market share, namely Shopee 27.4 percent, Lazada 14.2 percent, Tokopedia 5.2 percent, Facebook 2.4 percent, Bukalapak 3.8 percent, Traveloka 1.3 percent, and KlikIndomaret 0.4 percent (Franedya, 2019). These data indicate competition is high, so reliable strategies are needed for every marketplace and business actor to gain a competitive advantage and sustainability. Some of the behaviors of Indonesian online shoppers have caused marketplaces and manufacturers to refine application details and product or service suitability. First, many customers prefer freebies overall, although that's not always the case. Second, enjoy online store discounts or coupons. Third, look for comparisons on product or service details. Fourth, choosing the lowest price with good quality. Fifth, fear of fraud, usually inspired by testimonials from other people or friends rather than what is stated in the ad. Lastly, simply by asking the seller's goods as a kind of consultation or merely looking for information (Dewantara, 2015).

Based on YLKI's complaint data for 2015-2019, online shopping complaints always occupy the first rating. In addition, there are also concerns about the still weak issue of consumer protection regulations in the e-commerce sector (http:/ / ylki.or.id/2017/03/siaran-pers-ylki-konsumen-belum-terlindungi-diera-ekonomi-digital/). One of the complaints experienced by consumers is that goods do not arrive, misuse of personal data, and marketing gimmicks that tend to deceive, so that consumers must always be vigilant in conducting online transactions. In the long term, this crisis of trust will be very detrimental to consumers and e-commerce producers. Therefore, from the producer's point of view, it is necessary to immediately address the sustainability of their business by rebuilding trust and improving e-service quality (Valarie A Zeithaml, 2000; Kundu \& Datta, 2015). Thus, the trust factor is the most critical factor influencing the way people shop on the internet based on the details provided by the seller on the website (Royvan Ghani, 2018).

Previous research has shown that service quality significantly influences customer happiness and contributes to a positive attitude, which leads to customer loyalty (Zia, 2015). In addition, customer loyalty is primarily based on the level of service provided, especially in the banking and market sectors (Hossain, Shan, Musa, \& Rahman, 2020). Meanwhile, service quality is described as an overall measure of the services offered to customers (Bitner et al., 1994; Ganguli \& Roy, 2011). Wu (2013) shows that customer satisfaction affects retention or loyalty intentions. Yeo et al. (2017) the research results to maintain customer loyalty in the online market, provide insight into the customer experience about service failures and help reduce losses. The study has shown the importance of customer satisfaction as a good mediator to increase customer loyalty. 
Similarly, trust plays an essential role in shaping psychological states with positive or negative feelings towards e-producers. Madiawati et al. (2021) explained that customer satisfaction significantly affects service quality to customer loyalty. In other words, Service quality has a significant effect on customer loyalty through customer satisfaction.

Some research found that customer satisfaction positively impacts customer loyalty (Izogo, 2015; Lee et al., 2011; Olorunniwo et al., 2006; A Parasuraman et al., 1988; V A Zeithaml et al., 2008). However, most are discussed from the organization in reality, and the mediator role of customer satisfaction who mediates two variables at once remains underexplored. Additionally, in Indonesia, no law serves as the legal cover for online retail operations yet, so customer trust becomes urgent to include investigation. Hence, from the point of organization in virtual or e-commerce and trust factor, this study will explore the mediating role of customer satisfaction between eservice quality, confidence, and customer loyalty.

\section{THEORETICAL REVIEW}

\section{Quality of Electronic Services (E-Service) to Customer Satisfaction}

Many supermarket reviews have looked at the definition of customer loyalty. Customers' loyalty has improved as a check determinant of the online market. According to Pham \& Ahammad (2017), customer satisfaction refers to a customer's cumulative experience of a product or service after they have purchased it. Meanwhile, Choi et al. (2013) argue that customers' loyalty is a product of the customer's buying experience, and it has an impact on potential behavior. Physical evidence (tangibles), durability, openness, assurance, and empathy are some of the metrics used to assess service efficiency (empathy) (Parasuraman et al., 2005).

The E-S-QUAL Multiple Item Scale for Assessing Electronic Service Quality was built based on previous studies. The E-S-QUAL scale has 22 items and four dimensions in this study: efficiency, compliance, system availability, and privacy. a). Efficiency: the ease and speed at which websites can be reached and used; b). Delivery: the network's capacity to guarantee order fulfillment and product supply; c). System availability: service infrastructure functionality; d). Privacy: the quality of site protection and user information safety. The E-Rec SQUAL scale has 11 components in three dimensions: responsiveness, returns, and contact, which would only help users who use the site regularly. (Parasuraman et al., 2005).

The connection between the standard of service and the degree of satisfaction is imminent (Fornell, 1992; Taylor \& Baker, 1994). The same outcomes are seen in the same sector, where the correct execution and practice of customer service quality is critical to increasing customers loyalty (Grönroos, 1984; A Parasuraman, Zeithaml, \& Berry, 1988; Walker, Johnson, \& Leonard, 2006). According to one of the service quality models, improving service quality would decrease disparities in team member engagement or, in other words, 
increase performance, which would positively impact customer satisfaction quality (Anantharanthan Parasuraman, Zeithaml, \& Berry, 1985). Customer loyalty, especially toward online service providers or marketplaces, will positively impact customer satisfaction. For this reason, hypotheses that can be formulated are as follows:

H1: Quality of electronic service is positively related to customer satisfaction.

Service Quality affects customer loyalty. Customers who are committed to the brand can help the business in a variety of ways. Marketplace customers who are already faithful to a service from their marketplace, for example, can seriously consider moving to another market to buy other brand goods (Mascarenhas, Kesavan, \& Bernacchi, 2006). Furthermore, researchers discovered a connection between perceived service quality and service loyalty (Bloemer, De Ruyter, \& Wetzels, 1999). Moreover, the standard of service would affect customer satisfaction and vice versa, providing the firm with a competitive advantage (Boulding, Kalra, Staelin, \& Zeithaml, 1993). In other research, it was discovered that the dimension of quality service and customers satisfaction have a beneficial relationship (Wong, Dean, \& White, 1999). Therefore, the proposed hypotheses include:

H2: Customer satisfaction is positively related to customer loyalty.

Customers' satisfaction is influenced by service quality, which is controlled by customer confidence. Excellent customer experience Quality will completely mediate part or all of the effect of quality service on customers' loyalty by belief. It will function as a catalyst that undermines the increasing importance of customer satisfaction (Roberts, Varki, \& Brodie, 2003). They should also consider why their service is deemed better than customers' by comparing service characteristics to fairness standards and care by other similar customers to improve and deliver high-quality services (Fang, Chiu, \& Wang, 2011). Several studies have shown that one of the individual components of service efficiency, customers trust, affects customer satisfaction (Chen, Liu, Sheu, \& Yang, 2012). Customer trust partially mediates the relationship between two factors, such as service efficiency and customer loyalty. One of the study's findings completely mediates the relationship between two other relevant dimensions. Consequently, it is clear that service quality influences customers' loyalty; good service quality will build a high level of customer satisfaction by establishing customer confidence (Namkung \& Jang, 2010). Therefore, the proposed hypotheses include:

H3: Customer satisfaction mediates the relationship between quality of electronic service and customer loyalty.

Customer trust affects customer satisfaction. Customer trust is a fundamental construct that influences marketing literature and customer behavior (Martínez \& Del Bosque, 2013). Customers place their confidence in a company's consistency and fairness when it comes to customer service. Customers usually perceive these marketplace firms as unethical in sharing 
information about undisclosed payments that would be paid to shoppers, such as stolen personal information and unclear practices. Hence, customers' expectations generally describe lousy service. As a result, winning customers' interest in the online retail industry is a daunting task.

Consequently, one of the most critical and decisive success and customer satisfaction measures is market loyalty (Rasheed \& Abadi, 2014). According to the findings, there is a strong correlation between happy shoppers and customers' trust in online shopping (Wu, 2013). Furthermore, recent studies have discovered a strong connection between customer loyalty and customer trust (Sirdeshmukh, Singh, \& Sabol, 2002). As a result, we believe that their level of confidence influences customers' loyalty. Therefore, a hypothesis that can be formulated is as follows:

H4: Customer trust is positively related to customer satisfaction.

Customers' satisfaction is influenced by customer confidence. Trust is a central element in forming long-term relationships (Singh \& Sirdeshmukh, 2000; Swan, Bowers, \& Richardson, 1999). Customer expectations of service provider reliability are shaped by customers' trust in the service sector, directly affecting service provider satisfaction (Sirdeshmukh et al., 2002). Customer retention is also a long-term commitment that demonstrates effective client-employee relationship management. Customer retention is also a long-term commitment that demonstrates effective client-employee relationship management (Silva \& Yapa, 2013). Furthermore, customer satisfaction can be engendered due to customer confidence (Ball, Coelho, \& Machás, 2004). Building on previous studies, it is clear that customer trust is essential in determining customer loyalty (Lau \& Lee, 1999). Therefore, in this study, the hypotheses used are:

H5: Customer trust is positively related to customer loyalty.

Trust affects customer loyalty through the quality of electronic services. Customer interest is vital in the e-commerce industry. Customer satisfaction and confidence are also linked to service efficiency. Customers need to trust the marketplace because internet sales require many individuals (Ribbink, van Riel, Liljander, \& Streukens, 2004). In addition, confidence and loyalty have been proposed as prerequisites for patronage activity that will support the corporation as the quality of service improves (Pavlou, 2003). Since shoppers and sellers cannot meet in person, confidence would be critical in introducing marketplace services (Papadopoulou, Andreou, Kanellis, \& Martakos, 2001). Several studies have been performed on the impact of online trust, engagement, and service quality (Reichheld \& Schefter, 2000); thus, the study's hypothesis is the following.

H6: Customer satisfaction mediates the relationship between customer trust and customer loyalty 


\section{METHODOLOGY}

In one of Indonesia's marketplaces, an extensive study was conducted on the efficiency of electronic services, trust, customer satisfaction, and customers' loyalty. The ESQUAL model is used in this research (Ananthanarayanan Parasuraman et al., 2005), which uses four dimensions: performance, fulfillment, device availability, and privacy. The following is a description of the structure: (1) efficiency: the ease with which the web can be reached and used; (2) fulfillment: the extent to which the site's promise of on-time delivery of orders and goods is kept; (3) system accessibility: the site's technological capabilities; (4) Confidentiality: the degree to which the platform protects and maintains user information. Furthermore, customer trust is measured using four indicators: (1) being willing to share sensitive knowledge (2). I'm ready to give the industry my phone number, (3) Marketplace In online sales, I've always been professional. (4) Marketplaces always deliver on their promises. Furthermore, two items were used to assess online satisfaction. According to Mohsin Butt \& Aftab (2013), customers' loyalty is measured using four criteria, among them: (1) I will tell others about the market where I buy my groceries (2). Others would benefit from my online marketplace, and I would recommend it to them (3). I want to continue to use my marketplace's online services (4). In comparison to other marketplaces, I like mine. The Likert scale is used to assess the effectiveness of electronic operations and trust, customer satisfaction, and loyalty (1 strongly disagree until five strongly agree).

This research aims to look at customer behavior in small markets. Practical sampling is used instead of probabilistic sampling methods. Researchers may use convenience sampling to collect available population samples. Convenience sampling was used to collect data due to time and cost constraints. It means data are collected along roads or time given and hence are not representative of the population of interest (Mohsin Butt \& Aftab, 2013). A total of 400 questionnaires were distributed, and usable responses were obtained 350, yielding a response rate of 87.5 percent. The respondents in this survey had used electronic resources in a marketplace, as evidenced by the hypothesis's acceptance. The Google Form tool is used to spread questionnaires. For three months in October, November, and December 2020, the study was performed in two areas in the province of West Java, namely Bogor Regency and Bogor City. A Likert scale was used to calculate all variables in this analysis. Indicators are measured using 5 -Likert scale, where $1=$ strongly disagree; $2=$ disagree; $3=$ neutral; 4 = agree and 5 = strongly agree.

The suggested research model was verified in this analysis by using the variance-based Structural Equation Modeling method (Partial Least Square). The PLS methodology can be used to assess latent processes that aren't broadly spread and that rely on data from medium or limited sample sizes (Ghozali, 2014). PLS was used to analyze the findings because it is an appropriate tool for evaluating the latent construction used in this study. Furthermore, this technique allows researchers to use small and medium sample sizes, and the data 
distribution is sporadic (Chin, Peterson, \& Brown, 2008). Meanwhile, the PLSSEM method is used to overcome the limitations of regression and factor-based SEM analyses when estimating highly complex mediation models. Even though it is employable at a small sample size, PLS-SEM displays a high level of statistical power (Hair et al., 2012; Sarstedt et al., 2020). Hence, in this study, the data analysis is not normally distributed, and mediation analysis is factor-based, so PLS-SEM is the appropriate approach to findings, interpretations, and conclusions. The research results were processed using the SmatPLS 3 software.

\section{RESULTS}

Respondent Profile. According to table 1, most customers' performing online transactions are women between the ages of 23 and 27, with a high school to S1 degree and a career or occupation as a professional or student. This finding is are in line with the results of other online transaction reports (Zia, 2020).

\begin{tabular}{llll}
\multicolumn{4}{c}{ Table 1. Respondent Profile } \\
\hline $\begin{array}{l}\text { Characteristics } \\
\text { Respondents }\end{array}$ & Description & Total & Percentage \\
\hline Gender & Male & 123 & $35 \%$ \\
Age & Female & 227 & $65 \%$ \\
& $18-22$ & 110 & $31 \%$ \\
& $23-27$ & 115 & $33 \%$ \\
Education & $28-35$ & 102 & $29 \%$ \\
& $36-40$ & 23 & $7 \%$ \\
& SD-SMP & 80 & $23 \%$ \\
& SMA-S1 & 95 & $56 \%$ \\
Job & S2 & 65 & $19 \%$ \\
& S3 & 10 & $3 \%$ \\
& Labor & 30 & $9 \%$ \\
& Housewife & 98 & $28 \%$ \\
& Student & 102 & $29 \%$ \\
& Employees & 56 & $16 \%$ \\
& Entrepreneur & 64 & $18 \%$ \\
\hline
\end{tabular}

Source: Results of data processing, 2020.

Measurement Model. To test and model measurements in this study, convergent validity $(\mathrm{AVE})>0.50$ and loading $>0.60$, discriminant validity $(\mathrm{CR}>$ $0.60)$, and composite reliability (CR, CA> 0.60) were used (Ghozali, 2014). The value $(\mathrm{AVE}>0.50$ and loadings $>0.60),(\mathrm{CR}>0.60)$, which indicates the integration is correct. The suit model has been determined using the parameters described above (See table 2). 
Table 2. Indicators for the Measurement Model

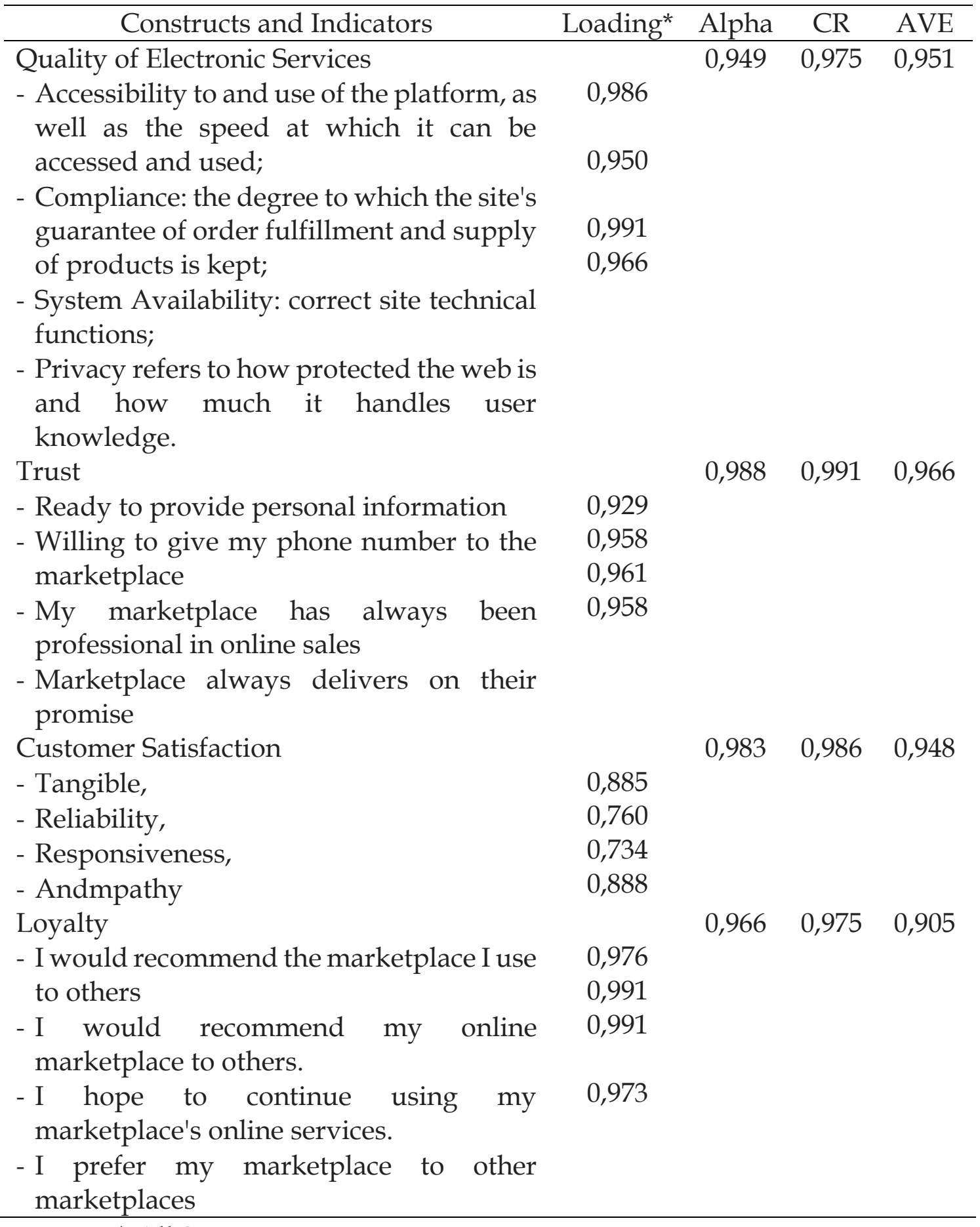

Note: *) All Sig. p<0.05

Source: Results of data processing, 2020

Based on the data in Table 2, where the importance of build Quality of Electronic Services is 0.949> 0.7, trust is 0.988> 0.7, Customer Satisfaction is $0.981>0.7$, and loyalty is $0.965>0.7$, the data can be inferred to have fulfilled the requirements. The average variance extracted (AVE) value can be inferred to 
have fulfilled the criteria for constructs Quality of Electronic Services of 0.951> 0.5 , Trust of $0.966>0.5$, Customer Satisfaction of $0.948>0,5$ and Loyalty of $0.905>$ 0,5 based on the average variance extracted (AVE) value.

Furthermore, Henseler et al. (2009) proposed an assessment of the correlation's heterotrait-monotrait ratio (HTMT). In short, HTMT is the ratio of the between-trait correlation to the within-trait correlation. HTMT is the average of all correlation indicators across constructs measuring different constructs (i.e., heterotraitmonotrait correlation) relative to the (geometric) mean of the correlation means of indicators measuring the same construct (i.e., heteromonotrait correlation; for a formal definition of HTMT statistics (Henseler et al., 2009). Technically, the HTMT approach estimates the accurate correlation between two constructs if they were perfectly measured (that is if they were completely reliable). This actual correlation is also referred to as desperate correlation. The desperate correlation between the two constructs close to 1 indicates a lack of discriminant validity.

Henseler et al. (2009) suggest a threshold value of 0.90 if the path model includes a conceptual construct. In other words, HTMT values above 0.90 indicate a lack of discriminant validity. When the constructs in the pathway model are conceptually more different, lower and more conservative threshold values appear necessary (Henseler et al., 2009).

Table 3. Evaluation of Heretroit-Monotrait (HTMT) Ratio

\begin{tabular}{|c|c|c|c|c|}
\hline & $\begin{array}{c}\text { Customer } \\
\text { Satisfaction }\end{array}$ & Loyalty & $\begin{array}{c}\text { Quality of Electronic } \\
\text { Services }\end{array}$ & Trust \\
\hline Customer Satisfaction & 0,823 & & & \\
\hline Loyalty & 0,844 & 0,830 & & \\
\hline Quality of E-Services & 0,873 & 0,768 & 0,879 & \\
\hline Trust & 0,943 & 0,850 & 0,876 & 0,820 \\
\hline
\end{tabular}

Source: Results of data processing, 2020

Table 4. The Results Of The Hypothesis Test

Path (Hypothesis) B p-value

\begin{tabular}{lll}
\hline E-Service Quality (X1) $\rightarrow$ Customer Satisfaction (Y1) & 0,075 & 0,008 \\
E-Service Quality (X1) $\rightarrow$ loyalty (Y2) & 0,082 & 0,041 \\
E-Service Quality (X1) $\rightarrow$ Customer Satisfaction (Y1) & & \\
$\rightarrow$ Loyalty (Y2) & 0,007 \\
Trust (X2) $\rightarrow$ Customer Satisfaction (Y1) & 0,000 \\
Trust (X2) $\rightarrow$ Loyalty (Y2) & 0,239 & 0,227 \\
Trust (X2) Customer $\rightarrow$ Satisfaction (Y1) $\rightarrow$ Loyalty (Y2) & & 0,000 \\
Customer Satisfaction (Y1) $\rightarrow$ Loyalty (Y2) & 0,219 & 0,000 \\
\hline
\end{tabular}

Significant at $p<0.05$

Source: Results of data processing, 2020 
According to the table 4, the result hypothesis testing that has been calculated states that the quality of e-service affects customer satisfaction $(=0.075$, $p$-value $=0.008)$, the quality of e-services affects customer loyalty $(=0.082, p$-value $=0.041)$, and trust positively affects customer satisfaction $(0.076, p$-value $=0.000)$. Thus, electronic service quality and satisfaction influence customer satisfaction by $89.9 \%$, while the remaining 10.1 percent is affected by other factors, and electronic service quality and satisfaction influence loyalty by 91.2 percent, and other unidentified factors affected the remaining 8.8 percent. Figure 1 summarizes the findings in the study relationships with substantial acceptance of all direct relationships.

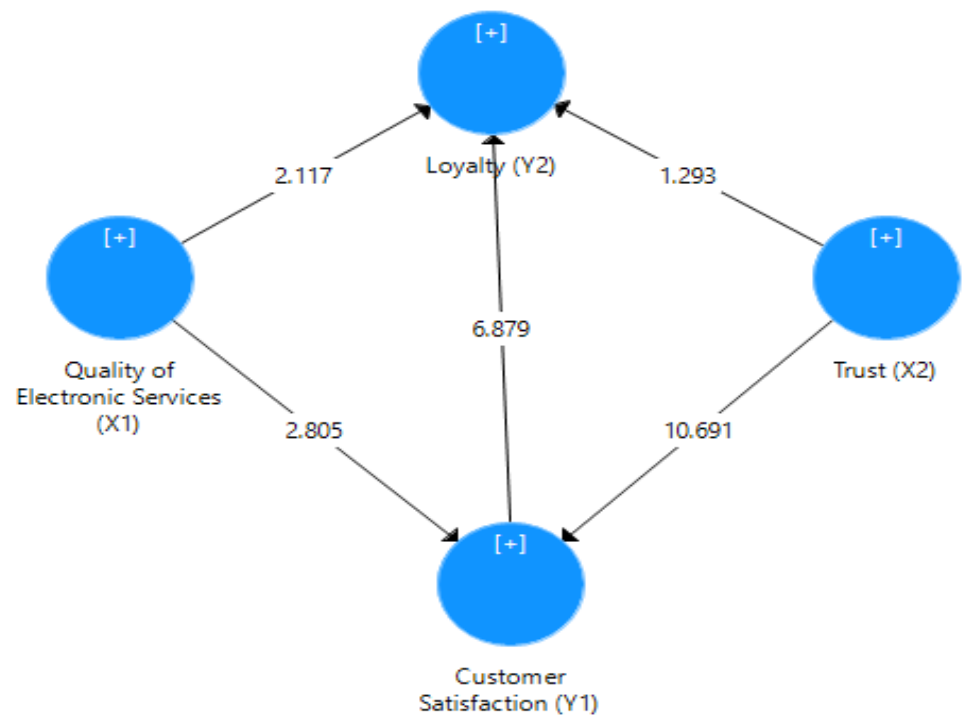

Figure 1. Depicts the relationship between the variables studied

Mediation Test. This study used a bootstrap strategy with a bias calibrated trust calculation, a confidence interval of 95 percent, and a set of 500 bootstraps to evaluate the position or mediation mechanism against the resulting values hypothesis H3 and H6 (Preacher \& Hayes, 2004). Customer satisfaction mediates the relationship between the level of electronic service and customer engagement, according to table 4 of the mediation test findings. Customer satisfaction mediates the relationship between trust and customer experience, with a $p$-value of 0.000 versus a baseline of $95 \%$ or an error of 0.05 , implying that the $H 3$ hypothesis may be partially accepted. Customer satisfaction mediates the relationship between trust and customer experience, with a $p$-value of 0.000 .

The final evaluation is the evaluation of the coefficient of determination $\left(R^{2}\right)$. Customer satisfaction has a determination coefficient of $0.808\left(R^{2}=80.8 \%\right)$, meaning that customer satisfaction can be explained by the construct of eservice quality and trust of $80.8 \%$, while other constructs define the remaining $19.2 \%$. Furthermore, the construct of loyalty can be explained by the constructs of e-service quality and trust of $83.2 \%$, while other constructs explain the remaining $16.8 \%$. Below, Table 5 shows that all the endogenous constructs are in the firm category. 
Table 5. Evaluation of R-square $\left(R^{2}\right)$

\begin{tabular}{l|c|c}
\hline Construct & $\mathbf{R}^{\mathbf{2}}$ & Category \\
\hline Customer Satisfaction & 0.808 & very strong \\
\hline Loyalty & 0.832 & very strong \\
\hline
\end{tabular}

Source: Results of data processing, 2020

\section{DISCUSSION}

According to data processing results, the quality of electronic services and the building of trust is the core determinant that affects customer retention and engagement when conducting online purchases in an E-Commerce (Badir \& Andjarwati, 2020). According to the study findings above, first-time customers' satisfaction has a substantial impact on customer retention. In e-commerce, fostering customers' interest is crucial. Second, the consistency of electronic service is an essential factor for promoting customer satisfaction and affecting customer engagement, so market leaders must pay close attention to it (Sharma \& Lijuan, 2015). Furthermore, the findings of the above study are consistent with previous studies, which found that customers' satisfaction is favorably influenced by service efficiency, with the influence between the two greater on a personal level or customer closeness relationship with its employers relative to its employees (Goff, Boles, Bellenger, \& Stojack, 1997). When a buyer is faithful to a distributor, he is also loyal to the related business (Díaz \& Duque, 2021). This viewpoint is supported by data showing that positive feelings regarding seller knowledge translate into positive emotions, implying that customer loyalty to the brand is realized by employee loyalty (Palmatier, Scheer, Houston, Evans, \& Gopalakrishna, 2007).

The significance of customer loyalty is highly influenced by solid contact and consistency in service quality (Bitner, Booms, \& Tetreault, 1990). The results of this study back up previous research that showed that service efficiency is a factor in customer satisfaction with the services provided (Han \& Hyun, 2017). The association between the efficiency of electronic services and customers engagement is often mediated by customer satisfaction (Vo \& Chovancová, 2019). The association between the efficiency of electronic services and customers engagement is often judged by customer satisfaction (Yoo, Huang, \& Kwon, 2015). Furthermore, according to previous studies, customers satisfaction mediates the interaction between confidence and customer loyalty (Zeithaml, Parasuraman, \& Malhotra, 2002).

In this study, the sample is millennials or also known as Generation Y. This generation is generally technology-minded and advanced in education. Therefore, their behavior is different from the previous generation. Research conducted by the Alvara Research Center found nine main behaviors of the Indonesian millennial generation: internet addiction, low loyalty, cashlessness, 
work smart and fast, multitasking, like to travel, indifferent to politics, likes to share, and the last is joint ownership of goods. From this behavior, e-commerce entrepreneurs can use the right strategies to gain trust and loyalty through eservice quality (Chang \& Sokol, 2020). For example, they are designing eyecatching products, ease of payment, easy access to applications, complaint service with problem-solved oriented, and always maintaining a positive image of the products or services offered (Cheah et al., 2018). The quality of service that built provide can build trust and satisfaction with each client (Gul et al., 2020; Kashif et al., 2018). Technology is advancing at a breakneck pace in the industrial world, and human needs are growing simultaneously (Buhalis et al., 2019), as technology is crucial in human life (Afzal et al., 2019).

Who can keep up with the exponential advancement in technology in this day and age? Times have evolved and become more advanced. New technologies is advancing at a breakneck pace (Xiang et al., 2015). There has been a large number of people who use internet-based technologies (Hartmann et al., 2015). The practice of disseminating, purchasing, selling, and promoting products and services via the internet network is known as the presence of trading with the internet or the so-called marketplace as a way of doing business. Online or shopping transfers make it easier to allow non-traditional payment transactions, such as using an interbank transfer scheme (Hossain \& Zhou, 2018).

\section{CONCLUSION, LIMITATIONS, AND FURTHER STUDY}

In this study, data processing has been conducted to determine the direct and indirect influence between constructs. The processing of the results of this study obtained that e-service quality and trust have a significant favorable influence on customer loyalty, and this effect is mediated by customer satisfaction. Although this study contributes to recent research on the impact of electronic service quality and trust on customer satisfaction and loyalty in conducting online transactions in a marketplace, there are some drawbacks. First, the data was collected only from users of electronic services in the city and district of Bogor alone. The region has not represented Indonesia as a whole, so the results of this study cannot be generalized to other areas of Indonesia. Therefore model used in this study is recommended to be reviewed from various other regions and, more specifically, the type of marketplace. This study focused only on variable electronic service quality, trust, satisfaction, and customer loyalty and does not include other variables such as image, after-sales service, and other socio-demographic factors that are potential determinants of customer satisfaction and loyalty. Therefore, studies that have a more extensive set of variables are valid. Third, the influence between variables may not be represented by the customer satisfaction and loyalty variables proposed in this study. Therefore, further research is recommended to use more extensive data and a wider coverage area to reflect the influence between variables, and the results may change over time. 


\section{REFERENCES}

Afzal, M. N. I., Gow, J., \& Rahman, A. (2019). Economic and Internet Growth Effect on Electricity Consumption in the BRICS Countries. International Advances in Economic Research.

Badir, M., \& Andjarwati, A. L. (2020). The Effect of E-WOM, Ease of Use and Trust on Purchase Decisions (Study on Tokopedia Application Users). Jurnal Minds: Manajemen Ide Dan Inspirasi.

Ball, D., Coelho, P. S., \& Machás, A. (2004). The role of communication and trust in explaining customer loyalty: An extension to the ECSI model. European Journal of Marketing.

Bitner, M. J., Booms, B. H., \& Mohr, L. A. (1994). Critical service encounters: The employee's viewpoint. Journal of Marketing, 58(4), 95-106.

Bitner, M. J., Booms, B. H., \& Tetreault, M. S. (1990). The service encounter: diagnosing favorable and unfavorable incidents. Journal of Marketing, 54(1), 71-84.

Bloemer, J., De Ruyter, K. O., \& Wetzels, M. (1999). Linking perceived service quality and service loyalty: a multi-dimensional perspective. European Journal of Marketing.

Boulding, W., Kalra, A., Staelin, R., \& Zeithaml, V. A. (1993). A dynamic process model of service quality: from expectations to behavioral intentions. Journal of Marketing Research, 30(1), 7-27.

Buhalis, D., Harwood, T., Bogicevic, V., Viglia, G., Beldona, S., \& Hofacker, C. (2019). Technological disruptions in services: lessons from tourism and hospitality. Journal of Service Management, 30(4).

Chang, H. H., \& Sokol, D. D. (2020). How incumbents respond to competition from innovative disruptors in the sharing economy - The impact of Airbnb on hotel performance. Strategic Management Journal.

Cheah, S., Ho, Y. P., \& Li, S. (2018). Business model innovation for sustainable performance in retail and hospitality industries. Sustainability (Switzerland), 10(11).

Chen, H., Liu, J. Y., Sheu, T. S., \& Yang, M. (2012). The impact of financial services quality and fairness on customer satisfaction. Managing Service Quality: An International Journal.

Chin, W. W., Peterson, R. A., \& Brown, S. P. (2008). Structural equation modeling in marketing: Some practical reminders. Journal of Marketing Theory and Practice, 16(4), 287-298.

Choi, E. K., Wilson, A., \& Fowler, D. (2013). Exploring customer experiential components and the conceptual framework of customer experience, customer satisfaction, and actual behavior. Journal of Foodservice Business Research, 16(4), 347-358.

Coyle, J. J., Bardi, E. J., \& Langley, C. J. (1992). The Managament of Business Logistics, West Publlishingn Company. St. Paul.

Devita, F. (2019). Pelayanan Mengecewakan dari Shopee - Media Konsumen. 
Dewantara, C. F. C. (2015). Analisis Dampak Penggunaan Situs Bukalapak. com Terhadap Perilaku Pembelian Pada Komunitas Samarinda Photographer. Tersedia Di Http://Ejournal. Ilkom. Fisip-Unmul. Ac. Id/Site/Wpcontent/Uploads/2015/06/Jurnal\% 20cesar \% 20done \% 20untuk\% 20dprint\% 20selesai\% 20j Umat, 20, 6-26.

Díaz, M. M., \& Duque, C. M. (2021). Open innovation through customer satisfaction: A logit model to explain customer recommendations in the hotel sector. Journal of Open Innovation: Technology, Market, and Complexity, $7(3)$.

Fang, Y., Chiu, C., \& Wang, E. T. G. (2011). Understanding customers' satisfaction and repurchase intentions: An integration of IS success model, trust, and justice. Internet Research.

Fornell, C. (1992). A national customer satisfaction barometer: The Swedish experifence. Journal of Marketing, 56(1), 6-21.

Franedya, R. (2019). Ini Toko Online yang Paling Sering Dikunjungi Orang RI.

Ganguli, S., \& Roy, S. K. (2011). Generic technology-based service quality dimensions in banking: Impact on customer satisfaction and loyalty. International Journal of Bank Marketing.

George, A., \& Kumar, G. S. G. (2014). Impact of Service Quality Dimensions in Internet Banking on Customer Satisfaction. Decision, 41(1), 73-85.

Ghozali, I. (2014). Structural Equation Modelling (SEM) metode alternative dengan Partial Least Square. Penerbit Universitas Diponegoro.

Goff, B. G., Boles, J. S., Bellenger, D. N., \& Stojack, C. (1997). The influence of salesperson selling behaviors on customer satisfaction with products. Journal of Retailing, 73(2), 171-183.

Grönroos, C. (1984). A service quality model and its marketing implications. European Journal of Marketing.

Grönroos, C. (2001). The perceived service quality concept-a mistake? Managing Service Quality: An International Journal.

Gul, G. N., Gul, G. F., Jing, Z., Gul, G. R., Zhenxing, G., \& Gul, G. W. (2020). The role of endorsers in bringing defunct brands back to life: theory and evidence. In Journal of Product \& Brand Management: Vol. ahead-of-p (Issue aheadof-print).

Gustafsson, A., Johnson, M. D., \& Roos, I. (2005). The effects of customer satisfaction, relationship commitment dimensions, and triggers on customer retention. Journal of Marketing, 69(4), 210-218.

Hair Jr, J. F., Hult, G. T. M., Ringle, C., \& Sarstedt, M. (2016). A primer on partial least squares structural equation modeling (PLS-SEM). Sage publications.

Hair, J. F., Sarstedt, M., Ringle, C. M., \& Mena, J. A. (2012). An assessment of the use of partial least squares structural equation modeling in marketing research. Journal of the Academy of Marketing Science, 40(3), 414-433. https://doi.org/10.1007/s11747-011-0261-6

Han, H., \& Hyun, S. S. (2017). Impact of hotel-restaurant image and quality of physical-environment, service, and food on satisfaction and intention. International Journal of Hospitality Management, 63, 82-92. 
Hashmi, A. R., \& Zia, A. (2020). customer relationship towards boundary spanner in-store (bakhala): a Saudi perspective. Academy of Marketing Studies Journal, 24(2), 1-8.

Henseler, J., Ringle, C. M., \& Sinkovics, R. R. (2009). The use of partial least squares path modeling in international marketing. In New challenges to international marketing. Emerald Group Publishing Limited.

Hossain, M. S., \& Zhou, X. (2018). Impact of m-payments on purchase intention and customer satisfaction : perceived flow as mediator. International Journal of Science and Business, 2(3), 503-517.

Hossain, S. F. A., Shan, X., Musa, M., \& Rahman, P. (2020). Social media and increased venture creation tendency with innovative ideas: the case of female students in Asia. In Handbook of research on managerial practices and disruptive innovation in Asia (pp. 194-209). IGI Global.

Izogo, E. E. (2015). Customers' service quality perception in automotive repair. African Journal of Economic and Management Studies.

Kashif, M., Zarkada, A., \& Ramayah, T. (2018). The impact of attitude, subjective norms, and perceived behavioural control on managers' intentions to behave ethically. Total Quality Management and Business Excellence, 29(5-6), 481501.

Kundu, S., \& Datta, S. K. (2015). Impact of trust on the relationship of e-service quality and customer satisfaction. EuroMed Journal of Business, 10(1), 21-46. https:// doi.org/10.1108/EMJB-10-2013-0053

Lau, G. T., \& Lee, S. H. (1999). Consumers' trust in a brand and the link to brand loyalty. Journal of Market-Focused Management, 4(4), 341-370.

Lee, J.-H., Kim, H.-D., Ko, Y. J., \& Sagas, M. (2011). The influence of service quality on satisfaction and intention: A gender segmentation strategy. Sport Management Review, 14(1), 54-63.

Liang, C.-J., \& Wang, W.-H. (2004). Attributes, Benefits, Customer Satisfaction and Behavioral Loyalty--An Integrative Research of Financial Services Industry In Taiwan. Journal of Services Research, 4(1).

Madiawati, P. N., Pradana, M., \& Miranda, S. (2021). Effects of Service Quality, Value Perception and Loyalty on Customer Satisfaction: Case of a Local Restaurant In South Bandung, Indonesia. Jurnal Bisnis Dan Manajemen, 22(1), 19-29.

Martínez, P., \& Del Bosque, I. R. (2013). CSR and customer loyalty: The roles of trust, customer identification with the company and satisfaction. International Journal of Hospitality Management, 35, 89-99.

Mascarenhas, O. A., Kesavan, R., \& Bernacchi, M. (2006). Lasting customer loyalty: a total customer experience approach. Journal of Consumer Marketing.

Mohsin Butt, M., \& Aftab, M. (2013). Incorporating attitude towards Halal banking in an integrated service quality, satisfaction, trust and loyalty model in online Islamic banking context. International Journal of Bank Marketing, 31(1), 6-23. https:// doi.org/10.1108/02652321311292029 
Namkung, Y., \& Jang, S. C. S. (2010). Effects of perceived service fairness on emotions, and behavioral intentions in restaurants. European Journal of Marketing.

Nyadzayo, M. W., \& Khajehzadeh, S. (2016). The antecedents of customer loyalty: A moderated mediation model of customer relationship management quality and brand image. Journal of Retailing and Consumer Services, 30, 262-270.

Olorunniwo, F., Hsu, M. K., \& Udo, G. J. (2006). Service quality, customer satisfaction, and behavioral intentions in the service factory. Journal of Services Marketing.

Palmatier, R. W., Scheer, L. K., Houston, M. B., Evans, K. R., \& Gopalakrishna, S. (2007). Use of relationship marketing programs in building customersalesperson and customer-firm relationships: Differential influences on financial outcomes. International Journal of Research in Marketing, 24(3), 210-223.

Papadopoulou, P., Andreou, A., Kanellis, P., \& Martakos, D. (2001). Trust and relationship building in electronic commerce. Internet Research.

Parasuraman, A, Zeithaml, V. A., \& Berry, L. (1988). SERVQUAL: A multipleitem scale for measuring consumer perceptions of service quality. 1988, 64(1), 12-40.

Parasuraman, Ananthanarayanan, Zeithaml, V. A., \& Malhotra, A. (2005). ESQUAL: A multiple-item scale for assessing electronic service quality. Journal of Service Research, 7(3), 213-233.

Parasuraman, Anantharanthan, Zeithaml, V. A., \& Berry, L. L. (1985). A conceptual model of service quality and its implications for future research. Journal of Marketing, 49(4), 41-50.

Pavlou, P. A. (2003). Consumer acceptance of electronic commerce: Integrating trust and risk with the technology acceptance model. International Journal of Electronic Commerce, 7(3), 101-134.

Pérez, A., \& Del Bosque, I. R. (2015). An integrative framework to understand how CSR affects customer loyalty through identification, emotions and satisfaction. Journal of Business Ethics, 129(3), 571-584.

Pham, T. S. H., \& Ahammad, M. F. (2017). Antecedents and consequences of online customer satisfaction: A holistic process perspective. Technological Forecasting and Social Change, 124, 332-342.

Preacher, K. J., \& Hayes, A. F. (2004). SPSS and SAS procedures for estimating indirect effects in simple mediation models. Behavior Research Methods, Instruments, \& Computers, 36(4), 717-731.

Rasheed, F. A., \& Abadi, M. F. (2014). Impact of service quality, trust and perceived value on customer loyalty in Malaysia services industries. Procedia-Social and Behavioral Sciences, 164, 298-304.

Reichheld, F. F., \& Schefter, P. (2000). E-loyalty: your secret weapon on the web. Harvard Business Review, 78(4), 105-113.

Ribbink, D., van Riel, A. C. R., Liljander, V., \& Streukens, S. (2004). Comfort your online customer: quality, trust and loyalty on the internet. Managing Service 
Quality: An International Journal, 14(6), 446-456. https:// doi.org/10.1108/09604520410569784

Roberts, K., Varki, S., \& Brodie, R. (2003). Measuring the quality of relationships in consumer services: an empirical study. European Journal of Marketing.

Royvan Ghani, 11311506. (2018). Peran Perantara E-Kepuasan dan EKepercayaan Pada Pengembangan E-Loyalitas Dalam Konteks Bisnis Online pada Pembelanja Online Wanita. Universitas Islam Indonesia.

Rychalski, A., \& Hudson, S. (2017). Asymmetric effects of customer emotions on satisfaction and loyalty in a utilitarian service context. Journal of Business Research, 71, 84-91.

Sarstedt, M., Hair, J. F., Nitzl, C., Ringle, C. M., \& Howard, M. C. (2020). Beyond a tandem analysis of SEM and PROCESS: Use of PLS-SEM for mediation analyses! International Journal of Market Research, 62(3), 288-299. https:/ / doi.org/10.1177/1470785320915686

Sharma, G., \& Lijuan, W. (2015). The effects of online service quality of ecommerce Websites on user satisfaction. The Electronic Library.

Silva, K. A., \& Yapa, S. (2013). Customer retention: with special reference to telecommunication industry in Sri Lanka.

Singh, J., \& Sirdeshmukh, D. (2000). Agency and trust mechanisms in consumer satisfaction and loyalty judgments. Journal of the Academy of Marketing Science, 28(1), 150-167.

Sirdeshmukh, D., Singh, J., \& Sabol, B. (2002). Consumer trust, value, and loyalty in relational exchanges. Journal of Marketing, 66(1), 15-37.

Swan, J. E., Bowers, M. R., \& Richardson, L. D. (1999). Customer trust in the salesperson: An integrative review and meta-analysis of the empirical literature. Journal of Business Research, 44(2), 93-107.

Taylor, S. A., \& Baker, T. L. (1994). An assessment of the relationship between service quality and customer satisfaction in the formation of consumers' purchase intentions. Journal of Retailing, 70(2), 163-178.

Walker, R. H., Johnson, L. W., \& Leonard, S. (2006). Re-thinking the conceptualization of customer value and service quality within the serviceprofit chain. Managing Service Quality: An International Journal.

Wong, A., Dean, A., \& White, C. (1999). The impact of service quality on customer loyalty in the hospitality industry. International Journal of Customer Relationship Management, 81-89.

$\mathrm{Wu}, \mathrm{L}$. (2013). The antecedents of customer satisfaction and its link to complaint intentions in online shopping: An integration of justice, technology, and trust. International Journal of Information Management, 33(1), 166-176.

Yeo, V. C. S., Goh, S. K., \& Rezaei, S. (2017). Consumer experiences, attitude and behavioral intention toward online food delivery (OFD) services. Journal of Retailing and Consumer Services, 35(July 2016), 150-162. https://doi.org/10.1016/j.jretconser.2016.12.013

Zeithaml, V A, Wilson, A., \& Bitner,blo M. J. (2008). Services marketing.. New Delhi. The McGraw-Hill Companies. 
Zeithaml, Valarie A, Parasuraman, A., \& Malhotra, A. (2002). Service quality delivery through web sites: a critical review of extant knowledge. Journal of the Academy of Marketing Science, 30(4), 362-375.

Zeithaml, Valarie A. (2000). Service quality, profitability, and the economic worth of customers: what we know and what we need to learn. Journal of the Academy of Marketing Science, 28(1), 67-85.

Zia, A. (2015). Transformational leadership a study of banking sector in Saudi Arabia. Global Journal of Management And Business Research.

Buhalis, D., Harwood, T., Bogicevic, V., Viglia, G., Beldona, S., \& Hofacker, C. (2019). Technological disruptions in services: lessons from tourism and hospitality. Journal of Service Management, 30(4).

Chang, H. H., \& Sokol, D. D. (2020). How incumbents respond to competition from innovative disruptors in the sharing economy - The impact of Airbnb on hotel performance. Strategic Management Journal.

Hartmann, B., King, W. P., \& Narayanan, S. (2015). Digital Manufacturing: The Revolution Will be Virtualized. McKinsey \& Company.

Vo, N. T., \& Chovancová, M. (2019). Customer satisfaction \& engagement behaviors towards the room rate strategy of luxury hotels. Tourism and Hospitality Management, 25(2), 403-420.

Xiang, Z., Schwartz, Z., Gerdes, J. H., \& Uysal, M. (2015). What can big data and text analytics tell us about hotel guest experience and satisfaction? International Journal of Hospitality Management, 44, 120-130. 